\title{
The Influence of Current Ratio, Quick Ratio and Net Profit Margin on Return on Investment at PT. Telekomunikasi Indonesia (Tbk) 2014-2018
}

\author{
Neneng Susanti \\ Universitas Widyatama \\ E-mail: neneng.susanti@widyatama.ac.id
}

(Received: January-2020; Reviewed: February-2020; Accepted: march-2020;

Avalaibel Online: March-2020; Published: March-2020)

S This is an open access article distributed under the Creative Commons Attribution License CC-BY-NC-4.0 @2020 by author (https://creativecommons.org/licenses/by-nc/4.0/)

\begin{abstract}
Financial management is very influential on the continuity of activities and the existence of a company and also affects every individual in the company. This study aims to determine the effect of the current ratio, quick ratio and net profit margin on return on investment at PT. Telekomunikasi Indonesia (Tbk) 2014-2018. The method used is explanatory research with a sample of 5 years of financial statements that have been made panel data. The analysis technique uses statistical analysis with regression testing, correlation, determination, and hypothesis testing. The results of this study the current ratio does not significantly influence the return on investment of $50.7 \%$, the hypothesis test obtained a significance of $0.177>0.05$. The quick ratio does not significantly influence the return on investment of $51.4 \%$, the hypothesis test obtained significance of $0.173>0.05$. Net profit margin has a significant effect on the return on investment of $86.6 \%$, hypothesis testing obtained significance of $0.022<0.05$. The current ratio, quick ratio, and net profit margin simultaneously have a significant effect on the return on investment of $99.2 \%$, hypothesis testing is obtained $19,836>9,280$..
\end{abstract}

Keywords: Current ratio, quick ratio, net profit margin, return on invesment.

\section{INTRODUCTION}

The development of technology today makes companies increasingly think hard to innovate and make their companies win the competition in the global market. Financial statements are very important tools to obtain information about the company's financial position and the results of operations achieved by a company. one form of information that can be used to determine the condition and development of a company (Harahap, 2009; Hery, 2019; Rudianto, 2012). Financial statements are basically the results of the accounting process that can be used as a tool to communicate between financial data or activities of a company with parties with an interest in the company's data or activities (Fahmi., 2011; Munawir, 2002; Umboh et al., 
Volume 3, Issue 2, March, 2020 Page. 127- 136

2013). Financial management is very influential on the continuity of activities and the existence of a company and also affects every individual in the company, therefore a manager is required to be able to run financial management properly (Brigham \& Houston, 2013; Ekawati, 2014; Farid Addy Sumantri et al., 2015; Horne, J.C. dan Wachowicz, 2007; Mahmudi, 2010; Syaifuddin, 2008). This is done so that the company can carry out the company's operational activities more effectively and efficiently. so the company can develop and maintain the company's activities and presence.

Table 1

Company data of PT. Telekomunikasi Indonesia Tbk. 2014 - 2018 (in billions of Rupiah)

\begin{tabular}{cccccc}
\hline Year & $\begin{array}{c}\text { Current } \\
\text { Asset }\end{array}$ & Current Debt & Stock & Total Equity & Net profit \\
& 33.075 & 28.437 & 509 & 77.424 & 20.290 \\
2014 & 33.762 & 31.786 & 474 & 86.125 & 21.446 \\
2015 & 47.912 & 35.413 & 528 & 93.428 & 23.317 \\
2016 & 47.701 & 39.762 & 584 & 105.554 & 29.172 \\
2018 & 47.561 & 45.376 & 631 & 112.130 & 32.701 \\
\hline
\end{tabular}

Based on the empirical data above we can see that: the company's current assets fluctuated where the company's assets experienced a two-fold decline in 2017 and 2018 compared to the previous year, current debts also fluctuated where each year experienced an increase, the company-owned inventory also fluctuated where every year has increased except in 2015 decreased compared to 2013, total equity also always increased from year to year while for the company's net profit every year has increased but smaller than the current debt obtained by the company.

Ratio analysis is a form or method commonly used in analyzing a company's financial statements (Erica, 2018; Harahap, 2007; Pramono, 2014). By using analysis tools in the form of this ratio will be able to explain or give an overview to the analyst about the good or bad situation or financial position in a company. Financial ratios are activities that compare numbers in a financial statement by dividing one number with another number (Kasmir, 2014; Puspitasari, 2011; Rusti'ani \& Wiyani, 2017; Satria, 2017). Comparisons can be made between one component with components in one financial statement or between components that exist between financial statements. Then the numbers being compared can be numbers in one period or several periods. By knowing the level of a company's Liquidity Ratio, it will be able to know the company's ability to meet short-term obligations with a guarantee of current assets (Amanah, Atmanto, \& Azizah, 2014; Antara, Sepang, \& Saerang, 2014; Mulyanti \& Supriyani, 2018; Yusra, 2016). Liquidity level is very useful for companies, especially creditors who provide short-term credit. And by knowing the Profitability Ratio, it will be able to know the company's ability to generate profits from its capital. This is very important to know how much the efficiency of a company PT. Telekomunikasi Indonesia Tbk is Badan Usaha Milik negara (BUMN) which is engaged in information and communication. 


\section{METHOD}

The type of research used is associative, where the aim is to find out the relationship between variables. The population in this study amounted to 5 years of financial statements that have been made panel data of PT. Telekomunikasi Indonesia (Tbk) 2014-2018. The sampling technique in this study is saturated sampling, where all members of the population are sampled. Thus the sample in this study amounted to 5 years' financial statements that had been made panel data. In analyzing the data used the instrument test, classical assumption test, regression, coefficient of determination and hypothesis testing.

\section{RESULT AND DISCUSSION}

Financial statements are very important tools to obtain information about the company's financial position and the results of operations achieved by a company. one form of information that can be used to determine the condition and development of a company

\section{Descriptive Analysis}

This test is used to determine the highest minimum and maximum scores, the average and standard deviations of each variable. The results are as follows:

Table 2

Descriptive Statistics Analysis Results

Descriptive Statistics

\begin{tabular}{lr|r|r|r|r}
\hline & N & \multicolumn{1}{c}{ Minimum } & Maximum & \multicolumn{1}{c}{ Mean } & Std. Deviation \\
\hline Current Ratio (X1) & 5 & 1.048 & 1.352 & 1.16480 & .122909 \\
& & & & & \\
\hline Quick Ratio (X2) & 5 & 1.034 & 1.338 & 1.14960 & .123074 \\
\hline Net Profit Margin (X3) & 5 & .227 & .254 & .24280 & .010521 \\
\hline Return on Investment (Y) & 5 & .093 & .111 & .10460 & .007369 \\
\hline Valid N (listwise) & 5 & & & & \\
\hline
\end{tabular}

The current ratio obtained a minimum percentage of $1.048 \%$ and a maximum percentage of $1.352 \%$ with an average of $1.164 \%$ with a standard deviation of $0.122 \%$. The quick ratio obtained a minimum percentage of 1.034 and a maximum percentage of 1.338 with an average of $1.149 \%$ with a standard deviation of $0.123 \%$. The net profit margin obtained a minimum percentage of $0.227 \%$ and a maximum percentage of $0.254 \%$ with an average of $0.242 \%$ with a standard deviation of $0.010 \%$. Return on investment obtained a minimum percentage of $0.093 \%$ and a maximum percentage of $0.111 \%$ with an average of $0.104 \%$ with a standard deviation of $0.007 \%$. 


\section{Regression Multiple Analysis}

This regression test is intended to determine changes in the dependent variable if the independent variable changes. The test results are as follows:

Table 3.

Multiple Regression Testing Results

\begin{tabular}{|c|c|c|c|c|c|c|}
\hline \multicolumn{7}{|c|}{ Coefficients $^{\mathrm{a}}$} \\
\hline \multirow{2}{*}{\multicolumn{2}{|c|}{ Model }} & \multicolumn{2}{|c|}{$\begin{array}{l}\text { Unstandardized } \\
\text { Coefficients }\end{array}$} & \multirow{2}{*}{$\begin{array}{l}\text { Standardized } \\
\text { Coefficients } \\
\text { Beta }\end{array}$} & \multirow[b]{2}{*}{$\mathrm{t}$} & \multirow[b]{2}{*}{ Sig. } \\
\hline & & $\mathrm{B}$ & Std. Error & & & \\
\hline 1 & (Constant) & -.049 & .041 & & -1.195 & .443 \\
\hline & Current Ratio (X1) & 1.496 & .581 & 24.954 & 2.575 & .236 \\
\hline & Quick Ratio (X2) & -1.503 & .581 & -25.096 & -2.588 & .235 \\
\hline & Net Profit Margin (X3) & .570 & .127 & .815 & 4.500 & .139 \\
\hline
\end{tabular}

a. Dependent Variable: Return on Investment (Y)

Based on the test results in the above table, the regression equation $\mathrm{Y}=-0.049+1.496 \mathrm{X} 1-$ $1.503 \mathrm{X} 2+0.570 \mathrm{X} 3$ is obtained. A constant of -0.049 means that if there is no current ratio and quick ratio, then there is a return on investment value of -0.049 points. Current ratio regression coefficient of 1.1496, this number is positive meaning that every time there is an increase in the current ratio of 1.1496, the return on investment will also increase by 1.1496 points. Quick ratio regression coefficient of -1.503 , this number is negative meaning that every time there is an increase in the quick ratio of -1.503 then the return on investment will also decrease by -1.503 points. Net profit margin regression coefficient of 0.570 , this number is positive, meaning that every time there is an increase in the net profit margin of 0.570 , the return on investment will also increase by 0.570 points.

\section{Correlation Coefficient Analysis}

Correlation coefficient analysis is intended to determine the degree of relationship strength of the independent variables on the dependent variable either partially or simultaneously. The test results are as follows:

Table 4.

Test Results Correlation Coefficient Current ratio Against Return on Investment

\begin{tabular}{llr|r}
\hline & \multicolumn{1}{c}{ Correlations $^{\mathbf{a}}$} \\
\hline & $\begin{array}{c}\text { Current Ratio } \\
(\mathrm{X} 1)\end{array}$ & $\begin{array}{c}\text { Return on } \\
\text { Investment (Y) }\end{array}$ \\
\hline Current Ratio (X1) & Pearson Correlation & 1 & -.712 \\
\cline { 2 - 4 } & Sig. (2-tailed) & & .177 \\
\hline Return on Investment (Y) & Pearson Correlation & -.712 & 1 \\
\cline { 2 - 4 } & Sig. (2-tailed) & .177 & \\
\hline
\end{tabular}

a. Listwise $\mathrm{N}=5$

Based on the test results obtained by the correlation value of -0.712 means that the current ratio has a strong negative relationship to return on investment. 
Table 5.

Test Results for Quick Ratio Correlation Coefficient Against Return on Investment.

Correlations $^{\text {a }}$

\begin{tabular}{llr|r}
\hline & & Qick Ratio (X2) & \multicolumn{1}{c}{$\begin{array}{c}\text { Return on } \\
\text { Investment (Y) }\end{array}$} \\
\hline Qick Ratio (X2) & Pearson Correlation & 1 & -.717 \\
& Sig. (2-tailed) & & .173 \\
\hline Return on Investment (Y) & Pearson Correlation & -.717 & 1 \\
& & & .173 \\
\cline { 2 - 4 } & Sig. (2-tailed) & & \\
\hline
\end{tabular}

a. Listwise $\mathrm{N}=5$

Based on the test results obtained by the correlation value of -0.717 means that the quick ratio has a strong negative relationship to return on investment.

Table 6.

Test Results Correlation Coefficient Net profit margin on Return on Investment.

Correlations $^{\text {b }}$

\begin{tabular}{llr|r}
\hline & & \multicolumn{1}{c}{$\begin{array}{c}\text { Net Profit } \\
\text { Margin (X3) }\end{array}$} & \multicolumn{1}{c}{$\begin{array}{c}\text { Return on } \\
\text { Investment (Y) }\end{array}$} \\
\hline Net Profit Margin (X3) & Pearson Correlation & 1 & $.931^{*}$ \\
\cline { 2 - 4 } & Sig. (2-tailed) & & .022 \\
\hline Return on Investment (Y) & Pearson Correlation & $.931^{*}$ & 1 \\
\cline { 2 - 4 } & Sig. (2-tailed) & .022 & \\
\hline
\end{tabular}

*. Correlation is significant at the 0.05 level (2-tailed).

b. Listwise $\mathrm{N}=5$

Based on the test results obtained by a correlation value of 0.931 means that the record has a very strong relationship to return on investment.

Table 7.

Test Results Correlation Coefficient Current ratio, Net profit margin, and Quick Ratio Simultaneously Against Return on Investment.

Model Summary

\begin{tabular}{lrr|rr|r}
\hline Model & R & R Square & \multicolumn{2}{c}{$\begin{array}{c}\text { Adjusted R } \\
\text { Square }\end{array}$} & $\begin{array}{c}\text { Std. Error of the } \\
\text { Estimate }\end{array}$ \\
\hline 1 & & $.992^{\mathrm{a}}$ & .983 & .934 & .001895 \\
\hline
\end{tabular}

a. Predictors: (Constant), Net Profit Margin (X3), Current Ratio (X1), Qick Ratio (X2)

Based on the test results obtained by the correlation value of 0.992 means that the current ratio, quick ratio, and net profit margin simultaneously have a very strong relationship to return on investment. 


\section{Analysis of the Coefficient of Determination}

Analysis of the coefficient of determination is intended to determine the percentage of influence of the independent variable on the dependent variable either partially or simultaneously. The test results are as follows:

Table 8.

Test Results for the Current Ratio Determination Coefficient on Return on Investment.

\begin{tabular}{|c|c|c|c|c|}
\hline \multicolumn{5}{|c|}{ Model Summary } \\
\hline Model & $\mathrm{R}$ & R Square & $\begin{array}{l}\text { Adjusted R } \\
\text { Square }\end{array}$ & $\begin{array}{l}\text { Std. Error of the } \\
\text { Estimate }\end{array}$ \\
\hline 1 & $.712^{\mathrm{a}}$ & .507 & .343 & .005975 \\
\hline
\end{tabular}

a. Predictors: (Constant), Current Ratio (X1)

Based on the test results obtained a determination value of 0.507 means that the current ratio has an influence contribution of $50.7 \%$ on return on investment.

Table 9.

Test Results for Quick Ratio Determination Coefficient on Return on Investment.

Model Summary

\begin{tabular}{|c|c|c|c|c|}
\hline Model & $\mathrm{R}$ & R Square & $\begin{array}{c}\text { Adjusted R } \\
\text { Square }\end{array}$ & $\begin{array}{l}\text { Std. Error of the } \\
\text { Estimate }\end{array}$ \\
\hline 1 & $.717^{\mathrm{a}}$ & .514 & .352 & .005932 \\
\hline
\end{tabular}

a. Predictors: (Constant), Quick Ratio (X2)

Based on the test results obtained a determination value of 0.514 means that the quick ratio has an effect contribution of $51.4 \%$ to return on investment.

Table 10.

Test Results Determination Coefficient Net profit margin on Return on Investment.

Model Summary

\begin{tabular}{lrr|rr|r}
\hline Model & $\mathrm{R}$ & \multicolumn{1}{|c|}{ R Square } & $\begin{array}{c}\text { Adjusted R } \\
\text { Square }\end{array}$ & $\begin{array}{c}\text { Std. Error of the } \\
\text { Estimate }\end{array}$ \\
\hline 1 & $.931^{\mathrm{a}}$ & .866 & .821 & .003115 \\
\hline
\end{tabular}

a. Predictors: (Constant), Net Profit Margin (X3)

Based on the test results obtained a determination value of 0.866 means that the net profit margin has an influence contribution of $86.6 \%$ on return on investment.

Table 11

Test Results for Determination Coefficient Current ratios, Quick Ratios and Net Profit Margins Against Return on Investment.

Model Summary

\begin{tabular}{lrr|rrr}
\hline Model & R & R Square & \multicolumn{1}{c}{$\begin{array}{c}\text { Adjusted R } \\
\text { Square }\end{array}$} & $\begin{array}{c}\text { Std. Error of the } \\
\text { Estimate }\end{array}$ \\
\hline 1 & & $.992^{\mathrm{a}}$ & .983 & .934 & .001895 \\
\hline
\end{tabular}

a. Predictors: (Constant), Net Profit Margin (X3), Current Ratio (X1), Quick Ratio (X2) 
Based on the test results obtained a determination value of 0.992 means that the current ratio, quick ratio, and net profit margin simultaneously have an influence contribution of $99.2 \%$ on return on investment, while the remaining $8.0 \%$ is influenced by other factors.

\section{Hypotesis Testing}

Hypothesis testing with a t-test is used to find out which partial hypotheses are accepted.

Table 12.

Hypothesis Test Results from Current ratio of Return on Investment.

\section{Coefficients $^{\mathrm{a}}$}

\begin{tabular}{|c|c|c|c|c|c|}
\hline \multirow[b]{2}{*}{ Model } & \multicolumn{2}{|c|}{$\begin{array}{l}\text { Unstandardized } \\
\text { Coefficients }\end{array}$} & \multirow{2}{*}{$\begin{array}{l}\text { Standardized } \\
\text { Coefficients } \\
\text { Beta }\end{array}$} & \multirow[b]{2}{*}{$\mathrm{t}$} & \multirow[b]{2}{*}{ Sig. } \\
\hline & $\mathrm{B}$ & Std. Error & & & \\
\hline (Constant) & .154 & .028 & & 5.427 & .012 \\
\hline Current Ratio (X1) & -.043 & .024 & -.712 & -1.756 & 177 \\
\hline
\end{tabular}

a. Dependent Variable: Return on Investment (Y)

Based on the test results in the above table, the value of $t_{\text {count }}<t_{\text {table }}$ or $(-1,756<3,182)$ is obtained, thus there is no significant effect between the current ratio to return on investment being received.

Table 13.

Quick Ratio Hypothesis Test Results on Return on Investment.

Coefficients $^{\mathrm{a}}$

\begin{tabular}{|c|c|c|c|c|c|c|}
\hline \multirow{2}{*}{\multicolumn{2}{|c|}{ Model }} & \multicolumn{2}{|c|}{$\begin{array}{c}\text { Unstandardized } \\
\text { Coefficients }\end{array}$} & \multirow{2}{*}{$\begin{array}{l}\text { Standardized } \\
\text { Coefficients } \\
\text { Beta }\end{array}$} & \multirow[b]{2}{*}{$\mathrm{t}$} & \multirow[b]{2}{*}{ Sig. } \\
\hline & & B & Std. Error & & & \\
\hline 1 & (Constant) & .154 & .028 & & 5.532 & .012 \\
\hline & Quick Ratio (X2) & -.043 & .024 & -.717 & -1.781 & .173 \\
\hline
\end{tabular}

a. Dependent Variable: Return on Investment (Y)

Based on the test results in the above table, the value of $t_{\text {count }}<t_{\text {table }}$ or $(-1.781<3.182)$ is obtained, thus there is no significant effect between the quick ratio of return on investment being received.

Table 14.

Hypothesis Test Results From Net Profit Margin on Return 0n Investment. Coefficients $^{\mathbf{a}}$

\begin{tabular}{|c|c|c|c|c|c|}
\hline \multirow[b]{2}{*}{ Model } & \multicolumn{2}{|c|}{$\begin{array}{l}\text { Unstandardized } \\
\text { Coefficients }\end{array}$} & \multirow{2}{*}{$\begin{array}{c}\text { Standardized } \\
\text { Coefficients } \\
\text { Beta }\end{array}$} & \multirow[b]{2}{*}{$\mathrm{t}$} & \multirow[b]{2}{*}{ Sig. } \\
\hline & $\mathrm{B}$ & Std. Error & & & \\
\hline $1 \quad$ (Constant) & -.054 & .036 & & -1.492 & .233 \\
\hline Net Profit Margin (X3) & .652 & .148 & .931 & 4.403 & .022 \\
\hline
\end{tabular}

a. Dependent Variable: Return on Investment (Y)

Based on the test results in the table above, the value of $t_{\text {count }}>t_{\text {table }}$ or $(4.403>3.182)$ is obtained, thus there is a significant effect of net profit margin on return on investment received. 
Volume 3, Issue 2, March, 2020 Page. 127- 136

Hypothesis testing with the F test is used to find out which simultaneous hypotheses are accepted.

Table 15.

Hypothesis Test Results from Current ratio, Quick ratio and Net profit margin Against Return on investment.

\begin{tabular}{|c|c|c|c|c|c|c|}
\hline \multicolumn{7}{|c|}{ ANOVA $^{a}$} \\
\hline \multicolumn{2}{|c|}{ Model } & Sum of Squares & $\mathrm{df}$ & Mean Square & $\mathrm{F}$ & Sig. \\
\hline 1 & Regression & .000 & 3 & .000 & 19.836 & $.163^{\mathrm{b}}$ \\
\hline & Residual & .000 & 1 & .000 & & \\
\hline & Total & .000 & 4 & & & \\
\hline
\end{tabular}

a. Dependent Variable: Return on Investment (Y)

b. Predictors: (Constant), Net Profit Margin (X3), Current Ratio (X1), Quick Ratio (X2)

Based on the test results in the table above, the calculated $F_{\text {count }}>F_{\text {table }}$ or $(19.836>9.280)$, thus the fourth hypothesis proposed that there is a significant influence between the current ratio, quick ratio and net profit margin on return on investment is accepted.

\section{CONCLUSION}

The current ratio does not significantly influence the return on investment with the contribution of influence of $50.7 \%$. Hypothesis testing obtained $t_{\text {count }}<t_{\text {table }}$ or $(-1,756<3,182)$. The quick ratio does not have a significant effect on the return on investment with a contribution of $51.4 \%$. Hypothesis testing obtained $t_{\text {count }}<t_{\text {table }}$ or $(-1.781<3.182)$. The net profit margin has a significant effect on the return on investment with an influence contribution of $86.6 \%$. Hypothesis testing obtained $t_{\text {count }}>t_{\text {table }}$ or $(4.403>3.182)$. The current ratio, quick ratio, and net profit margin have a significant effect on return on investment with a contribution of $99.2 \%$ while the remaining $8.0 \%$ is influenced by other factors. Hypothesis testing obtained $\mathrm{F}_{\text {count }}>\mathrm{F}_{\text {table }}$ or $(19.836>9.280)$

\section{REFERENCES}

Amanah, R., Atmanto, D., \& Azizah, D. F. (2014). Pengaruh Rasio Likuiditas dan Rasio Profitabilitas Terhadap Harga Saham. Jurnal Administrasi Bisnis.

Antara, S., Sepang, J., \& Saerang, I. S. (2014). Analisis Rasio Likuiditas, Aktivitas, Dan Profitabilitas Terhadap Return Saham Perusahaan Wholesale Yang Terdaftar Di Bursa Efek Indonesia. Jurnal Riset Ekonomi, Manajemen, Bisnis dan Akuntansi.

Brigham, E. F., \& Houston, J. F. (2013). Dasar-Dasar Manajemen Keuangan. Salemba Empat. https://doi.org/10.1145/2505515.2507827

Ekawati, E. (2014). Manajemen Keuangan. Modul Kuliah. https://doi.org/10.1016/S00448486(98)00413-X

Erica, D. (2018). Analisa Rasio Laporan Keuangan Untuk Menilai Kinerja Perusahaan PT Kino Indonesia Tbk. Ecodemica.

Fahmi. (2011). Analisis Laporan Keuangan. Edisi ke-10. Lampulo:Aalfabeta. 
Farid Addy Sumantri, Nila, K., Fenti, H., Hery, Sugiyono, Aditya Setiawan, I. P. D., ... Pudjiastuti, S. H. dan E. (2015). Manajemen Keuangan Perusahaan. In Jurnal Ekonomi dan Bisnis. https://doi.org/10.24843/ejmunud.2018.v07.i05.p01

Harahap, S. S. (2007). Analisis Krirtis Atas Laporan Keuangan. Jakarta: PT.Raja Grasindo Persada.

Harahap, S. S. (2009). Analisa Kritis Laporan Keuangan. In Teori Akuntansi. https://doi.org/www.rajagrafindo.com

Hery. (2019). Akuntansi Dasar 1 dan 2. Fundamental Management Journal.

Horne, J.C. dan Wachowicz, J. M. (2007). Prinsip-Prinsip Manajemen Keuangan. In PrinsipPrinsip Manajemen Keuangan. https://doi.org/10.4324/9781315641348

Kasmir. (2014). Bank dan Lembaga Kuangan Lainnya. In PT. Raja Grafindo Persada jakarta.

Mahmudi. (2010). Manajemen Keuangan Daerah. In dalam pelaksanaan otonomi daerah dan desentralisasi fiskal, pemerintahan dituntut untuk memiliki kenandirian keuangan daerah yang lebih besar. Dengan tingkat kemandirian keuangan yang lebih besar berarti daerah tidak akan lagi sangat bergantung pada bantu.

Mulyanti, D., \& Supriyani, R. L. (2018). Pengaruh Perputaran Kas dan Perputaran Persediaan Terhadap Likuiditas pada PT Ultra Jaya, Tbk. Jurnal Kajian Ilmiah. https://doi.org/10.31599/jki.v18i1.180

Munawir. (2002). Analisis Laporan Keuangan. Yogyakarta: Liberty. Jurnal Riset Manajemen dan Bisnis.

Pramono, J. (2014). Analisis Rasio Keuangan Untuk Menilai Kinerja Keuangan Pemerintah Daerah. Jurnal Ilmiah Among Makarti.

Puspitasari, N. (2011). Analisis Keuangan Dinamis pada Manajemen Keuangan Bisnis Asuransi Umum Syariah. Junal Managemen Teknologi.

Rudianto. (2012). Pengantar Akuntansi Konsep \& Teknik Penyusunan Laporan Keuangan. In laporan arus kas adalah alat pembayaran yang dimiliki perusahaan dan siap digunakan untuk investasi maupun menjalankan operasi perusahaan setiap saat dibutuhkan.

Rusti'ani, M. E., \& Wiyani, N. T. (2017). Rasio Keuangan Sebagai Indikator Untuk Mengukur Kinerja Keuangan Perusahaan Semen. Rasio Keuangan Sebagai Indikator Untuk Mengukur Kinerja Keuangan Perusahaan Semen.

Satria, R. (2017). Analisis Laporan Keuangan Untuk Melihat Kinerja Perusahaan Pada PT. Darma Henwa Tbk. Jurnal Sekuritas.

Syaifuddin. (2008). Manajemen Keuangan (Teori dan aplikasi). 2008. https://doi.org/10.1017/CBO9781107415324.004

Umboh, D. J., Mangantar, M., Saerang, I. S., Sam, U., Manado, R., Supit, Y., ... Afandi, D. (2013). Analisis Laporan Keuangan. Journal of Chemical Information and Modeling. https://doi.org/10.1017/CBO9781107415324.004

Yusra, I. (2016). Kemampuan Rasio Likuiditas dan Solvabilitas dalam Memprediksi Laba Perusahaan : Studi Empiris pada Perusahaan Telekomunikasi. jurnal Benefita. 
136 Pinisi Discretion Review

Volume 3, Issue 2, March, 2020 Page. 127- 136 